\title{
IAMJ
}

INTERNATIONAL AYURVEDIC MEDICAL JOURNAL

\section{CONCEPTUAL STUDY OF ANATOMICAL CHANGES IN SHUKRAVAHA STROTAS IN VANDHYATVA W.S.R TO MALE INFERTILITY}

\author{
$\underline{\text { Ketan L. Tamhankar }}^{1}, \underline{\text { Gopal B. Sharma }}{ }^{2}, \underline{\text { Bhaoorao E. Borkar }}^{3}$
}

${ }^{1}$ PG Scholar, ${ }^{2}$ Professor, ${ }^{3}$ Professor \& HOD

Dept. of Rachana Sharir, Government Ayurveda College \& Hospital, Nagpur, Maharashtra

Corresponding Author: ketamh1677@gmail.com

\section{https://doi.org/10.46607/iamj1909042021}

(Published online: April 2021)

Open Access

(C) International Ayurvedic Medical Journal, India 2021

Article Received: 24/03/2021 - Peer Reviewed: 30/03/2021 - Accepted for Publication: 31/03/2021

\section{Check for updates}

\begin{abstract}
Infertility is typically defined as the inability to conceive after at least one year of regular, unprotected sex. This affects $15-20 \%$ of couples. A male factor is estimated to be present in about $50 \%$ of cases. Male infertility is associated with significant psychosocial and marital stress. In Sharir Sthana 'Mahatigarbhavktanti 'Adhyay Charaka mentioned about male infertility (Vandhyatva) and female infertility (Vandhyaatva). Vrushana and Shepha are Moola of Shukravaha Strotas. Testis and Vrushana, penis and Shepha can be correlate, so that the spermatogenesis and carrying of semen takes place. Shukra can be classified as Sukshma (invisible form of Shukra) and Sthula Shukra (semen). Vrushana and Shepha can considered as Moola Sthana with respect to Sthula Shukra. There are wide range of conditions causing male infertility. Out of which some causes anatomical change in Shukravaha Strotas which affects Parinaman (production) and Abhivahan (transportation) of Sthula Shukra.
\end{abstract}

Keywords: Shukravaha strotas, Strotomoola, Shukra, Vandhyatva, Male infertility

\section{INTRODUCTION}

Dharma-Artha-Kama-Moksha are the purposes of life ${ }^{[1]}$ Kama means to fulfil our desires. Sexual desire is having out most important for existence and propagation of our generations. Infertility is a disease of the male or female reproductive system defined by the failure to achieve a pregnancy after 12 months or more of regular unprotected sexual intercourse. In Sharirsthana 'Mahatigarbhavkranti Adhyay' Charaka mentioned 
male infertility as (Vandhyatva) and female infertility $($ Vandhyaatva $) .^{[2]}$

A Male factor is estimated to be present in about $50 \%$ cases with sole responsibility in $30 \%$ cases. ${ }^{[3]}$ Today increase in male infertility cases due to low sperm count (oligospermia) and reduced motility of sperms, absence of seminal fluid, absence of sperms (azoospermia etc.). Male infertility can be caused by wide range of conditions. Male infertility is associated with significant psychological and marital stress.

In Samhitas explanation about Shukra, Shukravaha Strotas and its defects are available. It's necessary to keep Shukravaha Strotas healthy for producing offsprings. The anatomical consideration of Shukravaha Strotas, Sushruta as well as Charaka and Vagbhata have different ideas. In Ayurveda Shukravaha Strotas is having broad aspect. Reproduction is one of main function of it. It is important to understand the structure and function of Shukravaha Strotas. Hence, study is undertaken to study reproductive element of Shukravaha Strotas and improve fertility prognosis of male patients.

Materials and Methods: Only textual materials are referred for present study. The principle Ayurvedic texts are referred in this study and modern books of renowned authors, as well as journals, website regarding male infertility have also been searched.

Shukravaha Strotas ${ }^{[4]}$ : Channels carrying the semen or reproductive tissue is called as Shukravaha Strotas. Those from which Sravana or those through which the Shukra flow in the body. Shukra transported through the channels from the place of production to place of need.

Strotomoola: The particular Strotas will develop from its Moola Sthana and few opinions that the Moola Sthana's act as the governing sites of that particular Srotas. According to Charaka the Vrushana and Shepha are the Moola of Shukravaha Srotas ${ }^{[5]}$. According to Sushruta the Stana and Vrushana are the Moola for the Shukravaha Srotas ${ }^{[6]}$. And according to Vagbhata the Stana, Vrushana and Majja Dhatu are the Moola for the Shukravaha Srotas ${ }^{[7]}$. According to Sharangdhara Vrushana are the root of Viryavahini Sira and through them Paurush (shukra) is discharge.
Sharangdhara proceeds further to note that Linga is a primary organ responsible for the creation of the Garbha and through it passes Shukra and Mutra. ${ }^{[8]}$

\section{Vrushana $^{[9]}$}

Definition-The organ, which produces Virya, is called as a Vrushana.

Vrushana Sthana-In Ashtang Hridaya Nidana Sthana in the context of organ present in Gudasti Vivara. Explained that vrushanas are the organs, which are present in Gudasti vivara.

Embryology of Vrushana- Sushruta in Sharir Sthana explained that Vrushanas origins from Prasadamasha (essence) part of Mamsa, Rakta, Kapha and Meda.

\section{Shukra Vahi Sira and Dhamanis ${ }^{[10]}$}

In Sushruta sharir sthana explained that 6 Dhamanis (urdhvaga 2 and adhoga 4) The Urdhvaga two are lactation pair this lactation pair is represented in male by seminal flow Where as 4 Adhoga are meant for producing Shukra (semen) and Shukra Visarga.In Sharangadhara Samhita explained that there are 2 Siras, which are attached to the Vrushana these helps in Shukra Vahana Karma. These 2 can be correlated with seminiferous tubules and vas deference

Medhra ${ }^{[11]}$ : Derivation-Medhra word is derived from mih + tra. Definition-The organ which carries the sperm to the vagina of Stree and which carries and excretes urine out of the body is called as Linga or Medhra

Shukradhara Kala ${ }^{[12]}$ : 7th Kala is called Shukradhara Kala (membranes or layers holding or preparing semen or reproductive fluid of man, which contains the sperms). This Kala is all pervading and is present in the whole body.

\section{Factors Responsible for Vandhyatva:}

1.Bijapradoshaj-Vitiation of part of Shukra through which male reproductive system will develop ${ }^{[13]}$

2.Shukradosha ${ }^{[14]}$-As a seed does not grow when impaired by un-seasonal implantation and when afflicted by water microbes, insects and fire, similarly the vitiated or polluted semen in human beings does not help in the precreation of an offspring.

Shukra Dosha Nidana: Excessive sexual indulgence, Excessive physical exercise, Intake of unwholesome food, Untimely sexual intercourse, Sexual intercourse 
through tracks other than the female genital organ, Abstinence from sexual rapport during appropriate time, Intake of food which are exceedingly dry, bitter, astringent, saline, sour and hot. Sexual intercourse with women who are not passionate. Old age, worry, grief and lack of confidence [in the sexual partner]. Injury by sharp instruments, Kshar application and $\mathrm{Ag}$ nikarma.Fear, anger and Abhichara, Emaciation by diseases, Suppression of the manifested natural Urges and, Injury to and vitiation of tissue elements

Because of the above-mentioned factors, the Doshas individually or jointly get aggravated, and reach the seminal channels instantaneously to vitiate the semen. 3.Klaibya ${ }^{[15]}$ - Chakrapani narrows the definition of Klaibya which means erectile dysfunction only. According to Charaka, A person even on having a strong sexual desire to perform sexual act with a beloved, willing and co-operative partner, he cannot perform coitus with $\mathrm{h}$ er due to lack of his penis erection or lack of penile rigidity.

Charaka said Klaibya is caused by the seminal morbidities i.e. Shukradosha and it gets corrected by the purification of the semen. Along with this anatomical point of view there are factors to be noted leads to non erectile phallus.

Cohabitation with young virgin girls, Sexual intercourse in parts other than vagina, Because of excitement and ignorance, sexual intercourse with a woman who is suffering from chronic diseases, in continuation who has shunned sexual relationship for a long time, who is in menstruation, and whose is offensive in smell, afflicted with diseases and has profuse discharge. Sexual intercourse with quadruped animals, Trauma to the phallus, not cleaning the phallus properly, Injury to the phallus by weapons, tech, nails, beating by a stick or compression, Excessive use of Shukas (a type of insect which is applied for the elongation of the phallus) and Suppression of the urge for seminal ejaculation during sexual intercourse.

Signs and symptoms

Swelling, pain and redness of the phallus, Serious types of pustular eruption in and suppression of the phallus, Fleshy growth in the phallus and its quick ulceration, Exudation which appears like rice water (Pulakodaka) or which is brownish black or pink in colour, Circular and hard indurations below the glans penis. Discharge of red, black, blue, turbid and red coloured liquid from the urethra. Acute burning sensation as if burnt by fire, and pain in the region of urinary bladder, testicles, perineal suture and groins. Discharge of slimy and paleyellow liquid at times. Mild swelling, numbness and scanty discharge. It takes long time to suppurate and may get abated quickly. Appearance of maggots in the phallus: Sloughing and foul smell of the phallus and dropping of the glans penis or of the whole penis or of the testicles.

\section{Embryonic Development And Spermatogenesis ${ }^{[16]}$}

The gonads either testes in males or ovaries in female contain respective primordial germ cells and these germ cells develop from undifferentiated genital ridge during 5 th week and the gonadal differentiation occurs in 7th week of embryonic life and similarly the sex ducts remain undifferentiated in early part of development. Both gonads and sex ducts become apparent during 3rd month of foetal life. Sex differentiation happens when the primordial germ cells originate in human embryos from endoderm of yolk sac and allantois. These cells migrate and reach genital ridge bilaterally in the later part of 5th week, usually gonads are indifferent ambisexual \& consists of outer cortex \& inner medulla. When germ cells appear in medulla of indifferent gonad, medulla differentiate to form testes (7th wk.) and cortex regress, resulting in the formation of spermatogonia. On the other hand, appearance of germ cells in the cortex induces the development of ovary in 8 " or 9th week and germ cells are transformed to oogonia. After differentiation of gonads, the foetal testis secretes two hormones such as protein hormone and Anti Mullerian hormone $(\mathrm{AMH})$ and these are responsible for the phenotypic male development. The steroid hormones secreted by Leydig's cells of foetal testes are testosterone and dihydrotestosterone (DHT), where the testosterone does the retention of mesonephric duct (primitive sex duct) and promoting its differentiation into duct system of testes and the DHT is responsible for male pattern of development before birth i.e. enlargement of and expression of male secondary sex characteristics. Spermatogonia developed from 
primordial germ cells that arise from yolk sac and enter testes during 5th week of development. Once spermatozoon is formed it is released in seminiferous tubules and the fluid for the sperm transport is produced by sertoli cells present in seminiferous tubules, the fluid pressure pushes sperm along the lumen of seminiferous tubules which reaches the rete testis via straight tubules and from there to coiled efferent ducts in epididymis, then vas deferens reaching to the ejaculatory duct and through urethra is ejaculated out". From this it is clear about the site of formation and path of ejaculation of shukra.

\section{Factors Responsible For Male Infertility ${ }^{[17]}$}

1.Primary Spermatogenic Failure-Testicular deficiency as a consequence of primary spermatogenic failure is caused by conditions other than hypothalamic-pituitary disease and obstruction of the male genital tract. It is the commonest form of reduced male fertility.

a. Congenital-Anorchia, Testicular dysgenesis/cryptorchidism, Genetic abnormalities.

b. Acquired-Trauma, testicular torsion, post-inflammatory forms, particularly mumps orchitis, exogenous factors (medications, cytotoxic or anabolic drugs, irradiation, heat), systemic diseases, testicular tumour, varicocele surgery that may compromise vascularisation of the testes and lead to testicular atrophy.

2.Genetic Disorders In Infertility-Chromosomal abnormalities, Genetic defects Y-chromosome and male infertility, Cystic fibrosis mutations and male infertility.

3.Obstructive Azoospermia-

- Intratesticular obstruction-Intratesticular obstruction occurs in $15 \%$ of men

- Epididymal obstruction it's a most common cause, affecting $30-67 \%$ of men

- Vas deference obstruction is the most common cause of acquired obstruction.

- Ejaculatory duct obstruction Is found in 1-3\% of cases.

4.Varicocele-Varicocele is a physical abnormality present in $11.7 \%$ of adult men and in $25.4 \%$ of men with abnormal semen analysis. The exact association between reduced male fertility and varicocele is unknown, but a recent meta-analysis showed that semen improvement is usually observed after surgical correction.

5.Hypogonadism-Hypogonadism is characterised by impaired testicular function, which may affect spermatogenesis and/or testosterone synthesis.

6.Cryptorchidism-Cryptorchidism is the most common congenital abnormality of the male genitalia and is found in $2-5 \%$ of new-born boys. Cryptorchidism is often associated with testicular dysgenesis and is a risk factor for infertility and GCT.

7.Male Accessory Gland Infections And InfertilityThe WHO considers urethritis, prostatitis, orchitis and epididymitis to be male accessory gland infections a.Epididymitis- Among sexually active men $<35$ years of age, epididymitis is most often caused by C. trachomatis or Neisseria gonorrhoea b.Mumps orchitis Mumps orchitis rarely leads to sterility but it may contribute to subfertility. It can also lead to oligospermia, azoospermia, and asthenospermia (defects in sperm movement). Unilateral disease can significantly, but only transiently, diminish the sperm count, mobility, and morphology.

8.Disorders Of Ejaculation-

a.Anejaculation-anejaculation involves complete absence of antegrade or retrograde ejaculation

b.Delayed ejaculation-In delayed ejaculation, abnormal stimulation of the erect penis is needed to achieve orgasm with ejaculation

c.Retrograde ejaculation-retrograde ejaculation is the total, or sometimes partial, absence of antegrade ejaculation as a result of semen passing backwards through the bladder neck into the bladder.

d.Premature ejaculation-premature ejaculation is a male sexual dysfunction characterised by ejaculation. Which always or nearly always occurs prior to or within about one minute of vaginal penetration. It does not impair fertility, provided intravaginal ejaculation occurs.

\section{DISCUSSION}

Shukra can be classified as Sukshma and Sthula Shukra. As the presence of Ghee in milk, sugar in the sugarcane similarly Sukshma Shukra is hidden in the body. ${ }^{[18]}$ Which can be understood by functions of shukra. It 
provides Dhairya, Chyavan, Preeti, Dehabala, Harsha. Sarvsharirgat Shukra can be understood by the involvement of multiple systems and action of hormones. Shukradharakala is present all over the body which tells us about Sukshma Shukra. It is hidden in the body which shows presence by the expulsion of Sthula Shukra. Which is ejaculated out through Shepha during sexual act. There are wide range of factors explained for male infertility in modern science. Out of which few causes male infertility due to anatomical changes in male external genitalia i.e. testis, penis and internal genital tract. According to embryological development, spermatogenesis and Shukravaha Strotas study testis and Vrushana, penis and Shepha can be correlate, so that the spermatogenesis and carrying of semen takes place. In Ayurveda anatomical changes can analyse by Shukravaha Strotas Vikruti. Vrushana and Shepha are Moolasthana with respect to Sthula Shukra. Factors like vasectomy, trauma, iatrogenic injury, prostate surgery, inguinal hernia, peyronie's disease can be relate to Sanga of shukra. Retrograde ejaculation relates to Vimargagaman of Shukra. Whereas varicocele, mumps orchitis, epididymitis, testicular atrophy affects Parinaman of Shukra. According to modern male infertility hinges on production and transport of sperm. In ayurveda it can correlate with Parinaman and Abhivahan of Sthula Shukra through Shukravaha Stroto Moolsthana. After diagnostic evaluation and analysing responsible factor will help for prognosis of male infertility patients.

\section{CONCLUSION}

We can say that there are anatomical changes in Shukravaha Strotas which affects Parinaman(production) and Abhivahan (Transportation) of Sthula Shukra leads to Vandhyatva.

\section{REFERENCES}

1. Agnivesha, Charaka Samhita with Ayurveda Dipika Commentary, Vd. Acharya Y.T, Choukambha Sanskrit Sansthan, Varanasi,2016 (Reprint), Sutrasthana 1/15: 6

2. Agnivesha, Charaka Samhita with Ayurveda Dipika Commentary, Vd. Acharya Y.T, Choukhambha Sanskrit Sansthan, Varanasi, 2016 (Reprint), Sharirsthana 4/3: 322
3. Dareen J Katz, Male infertility-The Other Side of Equation vol.46, NO.9, September 2017

4. Agnivesha, Charaka Samhita with Ayurveda Dipika Commentary, Vd. Acharya Y.T, Choukhambha Sanskrit Sansthan, Varanasi,2016 (Reprint), Vimanasthana 5/4: 250

5. Agnivesha, Charaka Samhita with Ayurveda Dipika Commentary, Vd. Acharya Y.T, Choukhambha Sanskrit Sansthan, Varanasi,2016 (Reprint), Vimanasthana 5/8: 251

6. Susruta Samhita by Ambika Dutta Shastri, Choukhamba Sanskrit Sansthan, Varanasi, reprint2009, Sharirsthana 9/12: 97

7. Astanga Samgraha by Ambika dutta shastri, Choukhamba Sanskrit Sansthan, Varanasi, reprint 2009, Sharirsthana 6/18: 57

8. Sharangadhar samhita by Smt Sailaeja Srivastava, Choukhamba Orientelia, Varanasi, Reprint 2011, Sharirsthana. 1/5/48: 44

9. Kundu debasis, Conceptual Study of Shukravaha Srotas With Its Mulasthana, Irjay, Vol3, Issue 2, Feb:2020;1-8

10. Kundu debasis, Conceptual Study of Shukravaha Srotas With Its Mulasthana, Irjay, Vol3, Issue 2, Feb:2020;1-8

11. Kundu debasis, Conceptual Study of Shukravaha Srotas With Its Mulasthana, Irjay, Vol3, Issue 2, Feb:2020;1-8

12. Susruta samhita by Ambika Dutta Shastri, Choukhamba Sanskrit Sansthan, Varanasi, reprint 2009, Sharirsthana 4/20: 357

13. Agnivesha, Charaka Samhita with Ayurveda Dipika Commentary, Vd. Acharya Y. T, Choukambha Sanskrit Sansthan, Varanasi,2016 (Reprint), Sharirsthana4/31:322

14. Agnivesha, Charaka Samhita with Ayurveda Dipika Commentary, Vd. Acharya Y. T, Choukambha Sanskrit Sansthan, Varanasi,2016 (Reprint), Chikitsasthana 30/135 -137: 640

15. Agnivesha, Charaka Samhita with Ayurveda Dipika Commentary, Vd. Acharya Y. T, Choukambha Sanskrit Sansthan, Varanasi,2016 (Reprint), Chikitsasthana 30/ 154-157: 64

16. TS Sajini', Midhu Parvathy', Anu Uthara Pious', Review On Shukra And Shukravaha Sroto Moola, IAMJ: Vol 3; issue 8; August 2015a

17. A. Jungwirth (Chair), T. Diemer, G.R Dohle, A. Giwercman, Z. Kopa, C.Krausz, H. Tournaye, Guidelines on Male Infertility, European Association of Urology 2015, Chpter 1-5:5-47

\section{Source of Support: Nil Conflict of Interest: None Declared}

How to cite this URL: Ketan L. Tamhankar et al: Conceptual Study Of Anatomical Changes In Shukravaha Strotas In Vandhyatva W.S.R To Male Infertility. International Ayurvedic Medical Journal \{online\} 2021 \{cited April, 2021\} Available from: http://www.iamj.in/posts/images/upload/805_809.pdf 